Department of Anatomy (Prof. Torao Yамамото)

Faculty of Medicine, Kyushu University, Fukuoka, Japan

\title{
Fine Structure of the Epithelium of the Gut in the Crayfish (Procambarus clarkii) with Special Reference to the Cytoplasmic Microtubules
}

\author{
Terumasa Komuro and Torao Yамамото \\ (小室 輝昌と山元 寅男)
}

Received September 5, 1968

The gut of the Decapod has been known to show many differences in histological structure from that of vertebrates; i.e., the foregut and hindgut of the Decapod possess cuticular coats composed of protein ground substance with chitinous fibrils, on the luminal surface of the gut epithelium, whereas the midgut lacks it (Huxley, 1881). Furthermore it has been reported that the muscle fibers of the gut wall attach themselves to the epithelium in the hindgut (VITzou, 1882) and also are attached to the cuticle by their tendons running upwards between the epithelial cells (FrENzeL, 1885). Thus the Decapod may, from the viewpoint of comparative anatomy, provide some interesting information on the structure and function of the intestine. However, very little is known about the fine details of the interesting structure of the Decapod gut at the electron microscopic level. The present work deals with the fine structure of the epithelium in the midgut and hindgut of the crayfish.

\section{Material and Methods}

Materials used for this study were adult crayfish of about $10 \mathrm{~cm}$ in body length, which were obtained from paddy fields or a pond near the University campus. Small pieces from the midgut and hindgut were removed from unanesthetized crayfishes into drops of fixative. After cutting into small bits, the specimens were fixed for two hours in ice cold $2 \%$ osmium tetroxide buffered at $\mathrm{pH} 7.4$ with phosphate butter (Millonig 1961). Other specimens were fixed for $2 \mathrm{hrs}$ in $5 \%$ glutaraldehyde buffered at pH 7.4 with a cacodylate buffer (SABATinI, et al., 1963) and then, postfixed for two hrs in buffered $2 \%$ osmium tetroxide. After dehydration in graded ethoanol, the specimens were embedded in Epon epoxy resin (LUFT, 1961). Thick sections for light microscopy were made with glass knives on a Porter-Blum microtome, and stained with $0.5 \%$ toluidine blue in a phosphate buffer at neutrality (Yамамото, 1963). Thin sections for electron microscopy were made in the same way as above, stained with a lead tartrate method (Millonig, 1961), and examined in an Hitachi HS-7 electron microscope. 


\section{Result}

\section{A. Light Microscopy}

The digestive tract consists of three parts: the foregut composed of the oesophagus and stomach, the midgut and the hindgut (HuxLey, 1881). The midgut is a very short part (a few $\mathrm{mm}$ in length) joining the stomach directly and bears a distincet striated border on the free surface of the epithelium (Fig. 1).

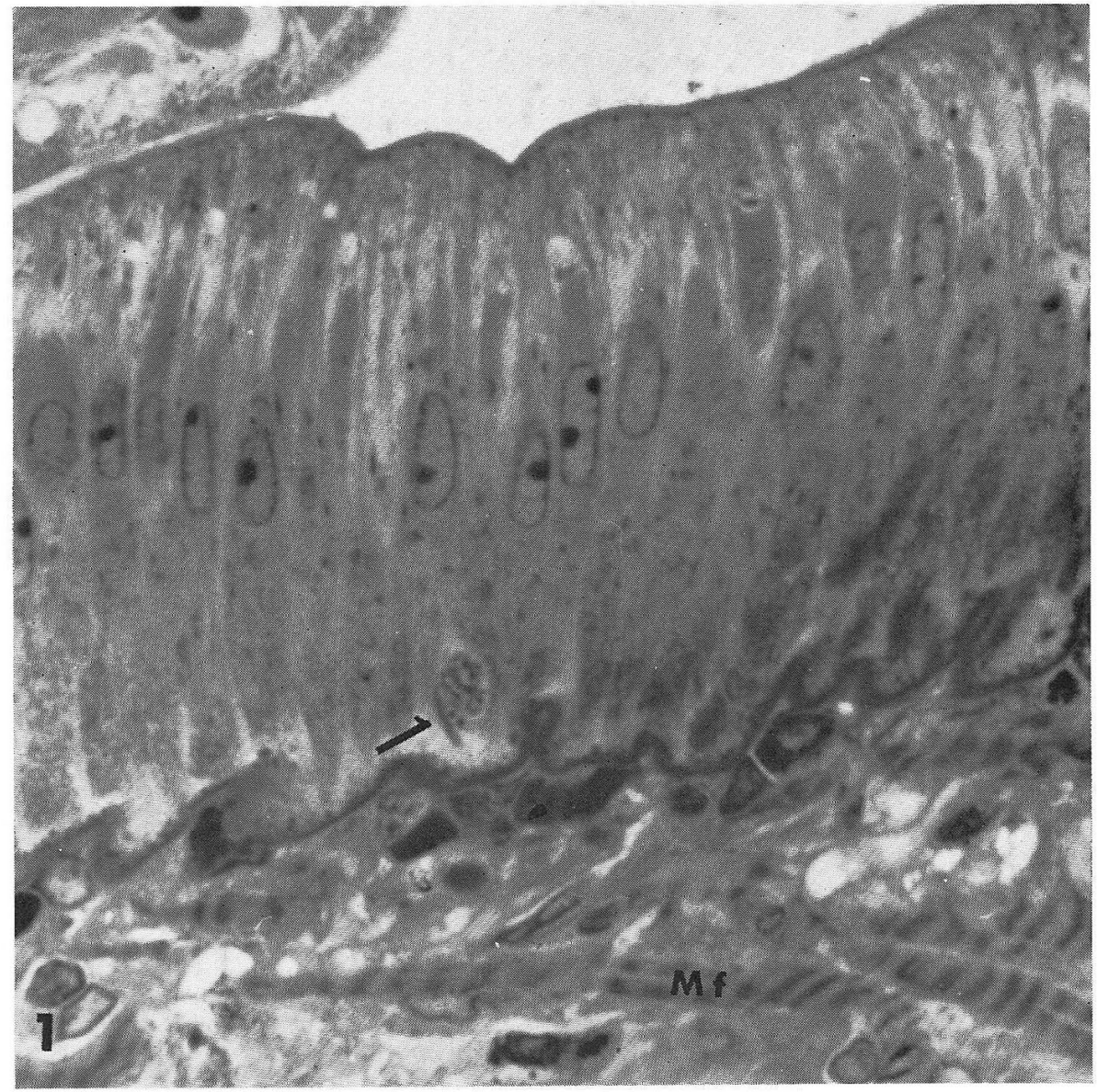

Fig. 1. A light micrograph showing the mucosa of the midgut. The epithelium mainly consists of tall columnar epithelial cells, which contains only a few granulated cells (arrow). Apical and basal granulations are noticed. Less dense, homogeneous area is observed in the supra-nuclear cytoplasm, which is clarified as the stacked lamellae of granular endoplasmic reticulm by electron microscopy. The subepithelial tissue contains a few of muscle fibers with striations $(M f) . \quad \times 500$

The hindgut following the midgut is about $6 \mathrm{~cm}$ in length and possesses a cuticular coat on the luminal surface of the epithelium. The midgut gland, which 
may be involved in the absorption of nutrients and in the secretion of the digestive enzymes (JoRDAN, $1904 \mathrm{~b}$ ), opens into the lumen at the anterior portion of the midgut through its ducts. The thin wall of the midgut is composed of the epithelium and its subjacent connective tissue and muscular coats. The epithelium consists of two types of cell ; one is a tall columnar cell (70-130 $\mu$ in height) and most numerous in population, whereas the other cell is assumed to represent the young stage of the former (FRENZEL, 1885). The muscular coats are seen fairly differentiated into an inner circular and an outer longitudinal layer, though both are poorly developed. The hindgut is a little different in structure from the midgut. In a cross section six large mucosal folds are usually observed in the hindgut. The epithelium is composed of only one type of cell: the columnar epithelial cells which are covered with a thick layer of cuticle.

The most apical cytoplasm of the epithelial cells show granular condensations in toluidine blue staining which may be attributed to the local concentration of the mitochondria. In the epithelium strand-like structures running parallel to the long axis of the epithelial cells can be recognized. Subepithelial tissues are particularly well developed in the most anterior portion of the hindgut, where the gut wall becomes much thicker circularly than in the remainder of the hindgut. Here one can find the connective tissue cells, some mucous cells, and a few striated muscle fibers.

Muscular coats consisting of striated muscle fibers are also recognized in the two layers. The inner longitudinal muscle layer is located at the base of the individual mucosal folds, whereas the outer circular one is very thin, though continuons in organization.

\section{B. Electron Microscopy}

\section{Epithelium of the midgut}

The columnar epithelial cells are tall, narrow cells with long nuclei located at the basal half of the cell. The luminal surface of these cells bears regular, but relatively sparse microvilli. The lateral surface of the cells makes smooth contact with neighboring cells (Fig. 2). Beneath the free surface individual cells are attached to the neighboring cells over a considerable distance along the length by unusual attachments which are quite similar to the zonula adherens, though not typical (Fig. 3). Tight junction and desmosome, which have been constantly found in mammalian intestinal epithelium, are not encountered here. The cytoplasm just beneath the microvilli is provided with a complex network of fine filamentous material called a terminal web, in which cell organelles are absent except for a few vesicles.

The apical cytoplasm below the terminal web shows a concentration of mitochondria which are mainly rod-shaped. Here also multivesicular bodies, agranular endoplasmic reticulum and vesicles, and a few cisternae of granular endoplasmic reticulum are scattered among the mitochondria. A variety of vacuoles which often contain membranous structures with myelin figures and dense vesicles, are occasionally encountered in this region (Fig. 2). The granular endoplasmic reticulum is well developed in the cytoplasm around the nucleus. The supra- 


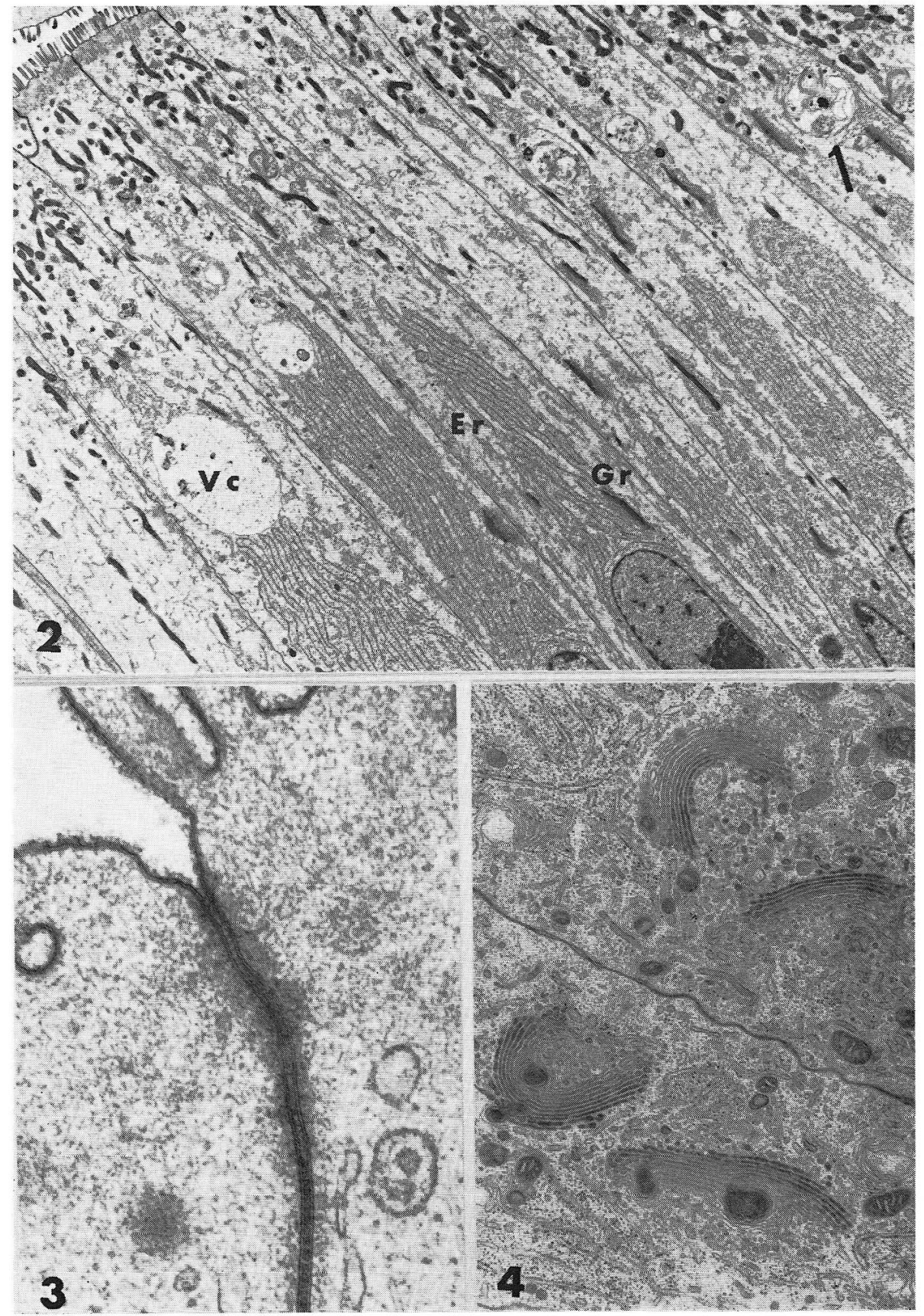

Fig. 2. An electron micrograph showing the apical half of the epithelial cells in the midgut. The luminal surface bears regular but sparse microvilli (at the left corner). The terminal web is distinct beneath the microvilli. Large vacuoles $(V c)$, phagosomes (arrow), and multivescular bodies are noticed in the apical cytoplasm. The supra-nuclear cytoplasm is occupied with the prominently stacked lamellae of granular endoplasmic reticulum (Er). The Golgi apparatus $(G r)$ is also located in proximity to the nucleus. $\cong 2,700$ 
nuclear region is remarkably tightly packed with the granular endoplasmic reticulum which is observed in the form of lamellae arranged parallel to the long axis of cells in the longitudinal section. The cross section shows a circular array of the lamellae of the granular endoplasmic reticulum around the nucleus. The Golgi apparatus which is mostly composed of stacked lamellae and a few vesicles is found well developed both in supra and infranuclear cytoplasm (Fig. 4).

The most characteristic feature of the cytoplasm is an extensive formation of unusual membranous structures which are best developed in the basal half of the cell (Fig. 5). These structures show various profiles in section; i.e., the most numerous is in the circular profile which is about $900 \AA$ in the diameter, and the others are tubular and lamelar (Fig. 6,7). The tubular structures are tortuous, sometimes branched channels with an almost constant diameter of about $900 \AA$. The circular profiles apparently represent the cross section of these tubules. Some of these tubules, which are located close to the lateral plasma membrane are seen to open into the intercellular spaces (Fig. 6). The lamellar structures are very flattened sacs which are bounded by two very regular parallel membranes separated by a distance of about $250 \AA$. Occasionally these lamellae show continuity to the tubular structure at one end. They are never associated with RNP particles. In the basal cytoplasm a number of mitochondria are particularly concentrated among the membranous structures above mentioned (Fig. 5, 6). No definite morphological relationship, however, can be recognized between these two components.

The epithelium usually rests on the thick basement membrane, but occasionally some cell processes which possess numerous vesicles containing moderately dense materials occur in between the basal plasma membrane and the basement membrane (Fig. 7). These cell processes resemble in appearance the nerve endings which have been reported in the nervous tissues of vertebrates.

Besides ordinary epithelial cells there can be observed another type of cell which is small, oval in shape and usually located close to the base of the epithelium (Fig. 5), though very infrequently. The cytoplasm contains mitochondria, a few dense granules, and poorly developed granular endoplasmic reticulum. No attachment apparatus seems to occur between these cells. This sort of cell appears to correspond to the basal cell described in light microscopy by FrEnZEL (1885). However, the cell may be migratory in nature.

\section{Epithelium of the hindgut}

The epithelium of the hindgut is composed of columnar cells alone, but is lower than that of the midgut. The luminal surface of the epithelial cells is covered with a thick cuticular coat which shows an alternating lamellar pattern of dense and light layers (Fig. 8,9). The whole thickness of the coat is variable (about $3-15 \mu$ ) from the top to the base of the mucosal folds. This coat is roughly divided into three layers: epicuticle, exocuticle and endocuticle, named from the luminal surface toward the base. The epicuticle is $0.5-1.0 \mu$ in thickness and shows a high electron opacity. The exocuticle is almost of the same thickness as the epicuticle,

Fig. 3. An unusual cell junction between adjacent epithelial cells of the midgut. No typical tight junction and desmosome are found. $\times 6,0000$

Fig. 4. A Golgi apparatus and its adjacent cytoplasm in an epithelial cell of the midgut. $\times 9,000$ 

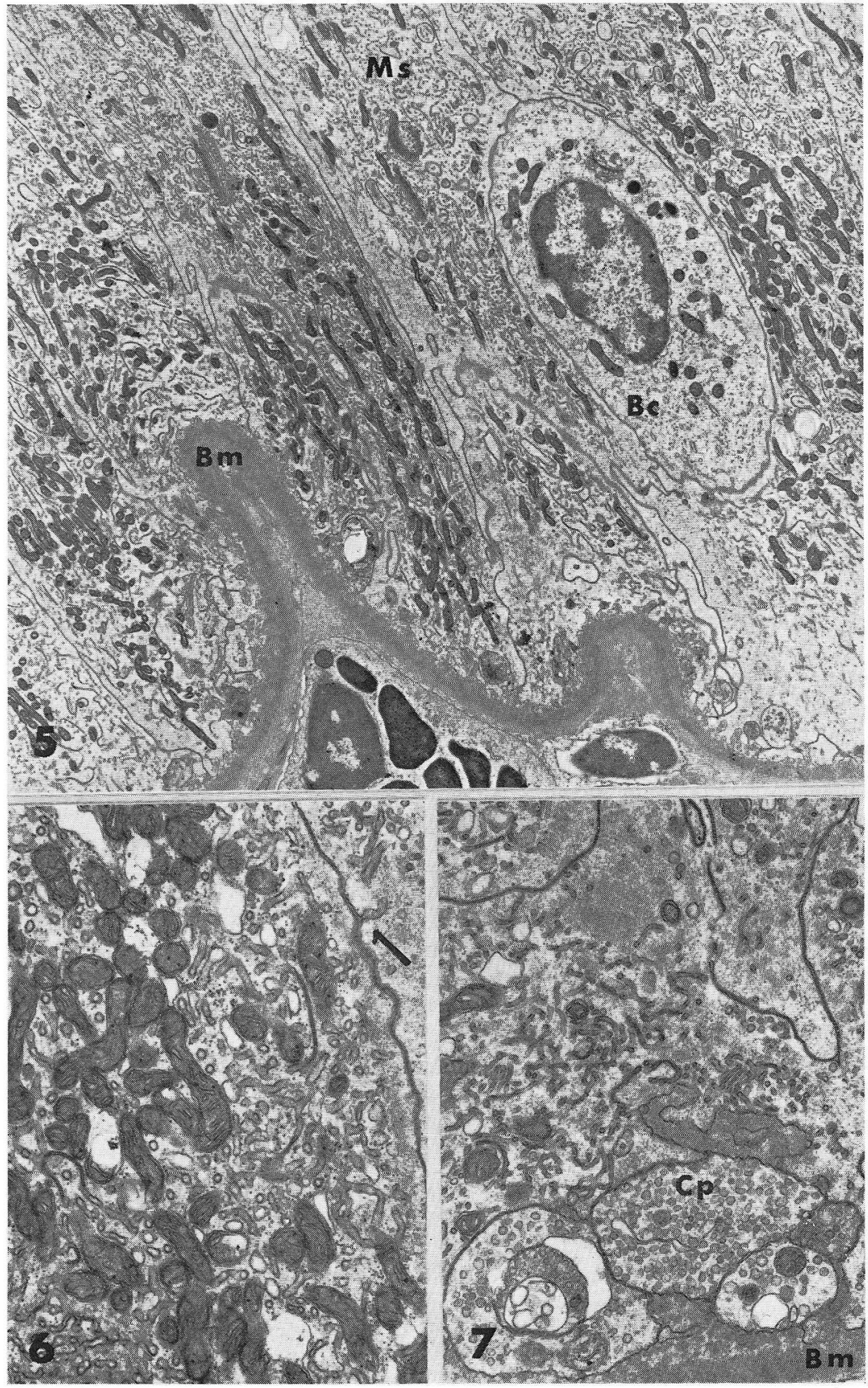

Fig. 5, 6, 7. For legend see p. 24. 
Fine Structure of the Epithelium of Crayfish Gut

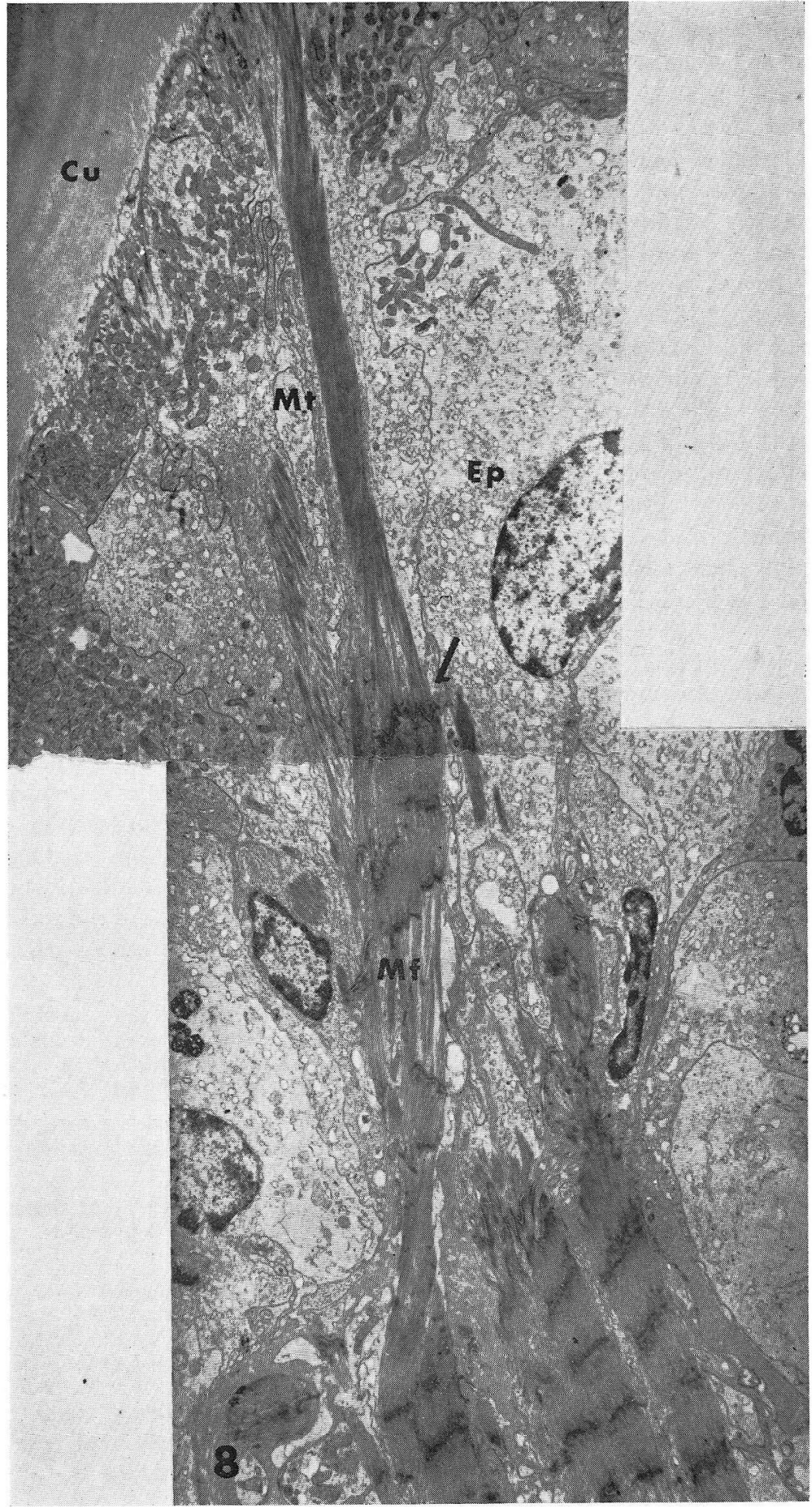

Fig. 8. For legend see p. 24. 
but is a little less dense. Thus, the exocuticle is distinguishable in electron opacity from the epicuticle. The endocuticle occupies the major part of the cuticular coat, and is variable in thickness from place to place. This layer may be subdivided into two layers (Locke, 1961). The first one subjacent to the exocuticle is composed of several lamellae with the fine filaments in alternate layers oriented at right angles to those in the intervening layers. However, the filaments constituting lamellae are not always arranged in regular direction, though often spread curling outwards. The second one is called Schmidt's layer or subcuticle (Schmidt, 1956 ; Locke, 1961) and not clearly arranged in the lamellae. Here a few filamentous materials are loosely arranged in various directions.

The epithelial cells possess finger-like cytoplasmic projections (a sort of microvilli) on the luminal surface and are embedded in the endocuticle materials. The luminal surface of the epithelial cells shows infrequent invaginations of plasma membrane, some of which are associated with the bristle coat.

The lateral surfaces of the cells show complicated interdigitations between adjacent cells at the upper half of the cell (Fig. 8). Beneath the free surfaces the neighboring cells are attached to each other by the zonula adhaerens (Fig. 10). Just below this junction occurs the typical septate desmosome (Fig. 10) which has been known to be present in the wide phyla of invertebrates (WooD, 1959, Loewenstein and Kanno, 1964 ; Wiener and Loewenstein, 1964 ; Locke, 1965). The septate desmosome is characterized by the presence of a septa across the intercellular space separated by a distance of about $280 \AA$. Each septum occur regularly at an interval of about $180 \AA$.

The apical cytoplasm is particularly concentrated by abundant mitochondria. It is characteristic of these epithelial cells that most mitochondria are confined to the apical cytoplasm (Fig. 8, 11). The Golgi apparatus composed of stacked lamellae and vesicles is located both in supra and infranuclear regions. The granular endoplasmic reticulum is in general scattered throughout the entire cytoplam, but most numerous in the supranuclear regions. Here the reticulum is mainly in vesicular form (Fig. 11). Among these granular vesicles are also seen

Fig. 5. The basal half of the epitelium in the midgut. Note the extensive formation of the tubular and lamellar membranous structures $(M s)$. Mitocondria are concentrated in close relation to these membranous structures. One basal cell $(B C)$ is seen embedded in between two adjacent epithelial cells. The epithelium rests on a thick basement membrane $(\mathrm{Bm}) . \quad \times 4,000$

Fig. 6. A higher magnification showing the tubular and lamellar membranous structures and the concentration of mitochondria in the base of the epithelium in the midgut. An arrow indicates the opening of the tubluar structure. $\times 13,000$

Fig. 7. The cell processes $(C p)$ containing numerous vesicles, which resemble in appearance the synaptic terminals of central nervous tissues, are present in the base of the epithelium, and closely contact with the basement membrane $(\mathrm{Bm}) . \times 12,000$

Fig. 8. The epithelium and its subjacent striated muscle fibers in the hindgut in a low magnification. The columnar epithelial cells $(E p)$ bear thick lamellated cuticle coat $(C u)$ on their luminal surface. Particular concentrations of mitochondria are seen mainly in the apical cytoplasm. The thick bundles of cytoplasmic microtubules $(M t)$ are observed attached to the plasma membranes of the apical and basal surfaces. The basal plasma membranes attached with microtubules make a junction (epithelio-myonal attachment, indicated by arrow) in zigzag form with those of striated muscle fibers $(M f)$, giving here the appearance resembling the intercalated disc in cardiac muscles. $\times 2,500$ 
dilated cisterns of the granular endoplasmic reticulum, the cavity of which is filled with electron lucent homogeneous materials (Fig. 11). Besides these cell organelles, glycogen granules and free ribosomes are seen scattered in the cytoplasm. The basal cytoplasm is evenly distributed by the vesicular elements of the granular endoplasmic reticulum and is usually devoid of mitochondria.

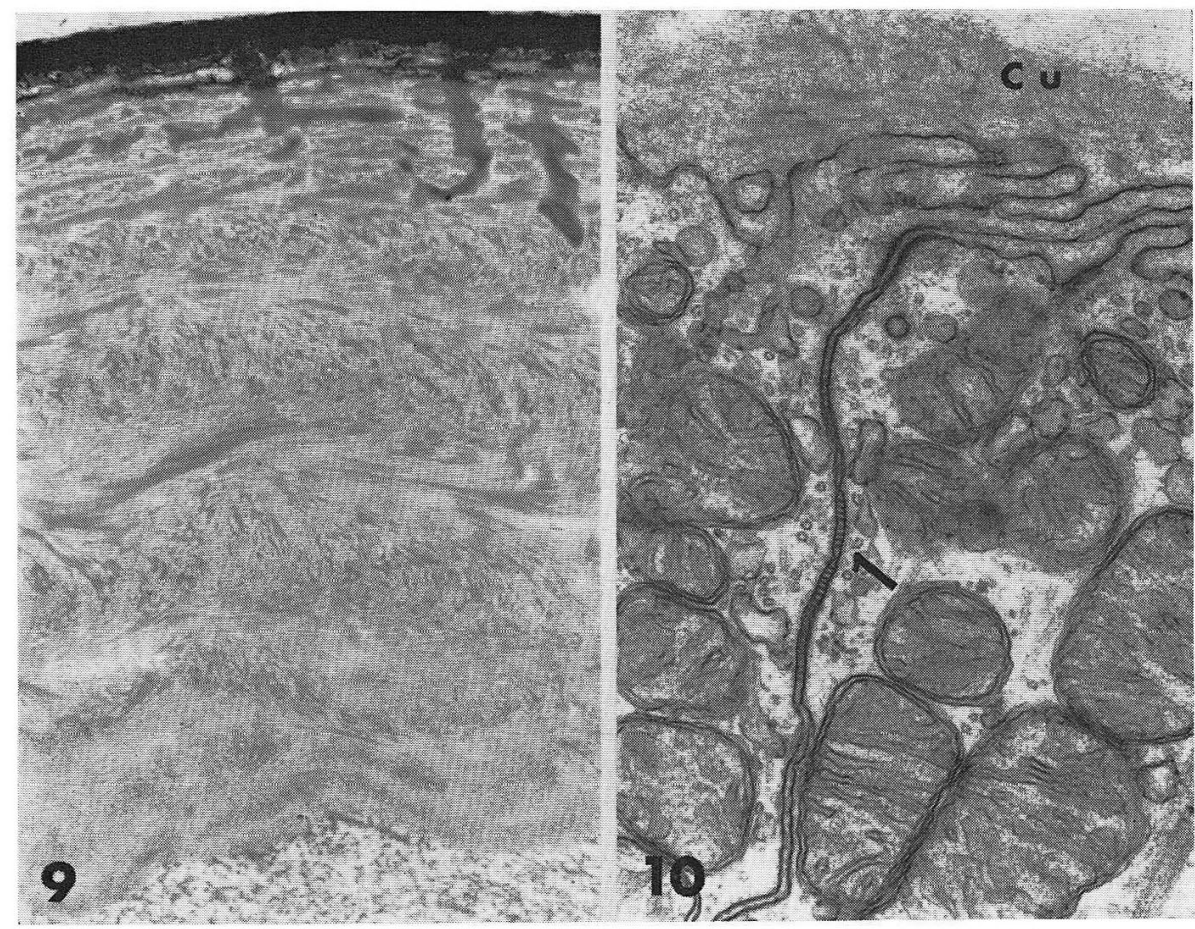

Fig. 9. Cuticular coat on the surface of the epithelium in the hindgut. $\Varangle 7,000$

Fig. 10. A high power electron micrograph showing the typical septate desmosome (arrow) between adjacent epithelial cells of the hindgut. The finger-like cytoplasmic projections into the cuticular coat $(\mathrm{Cu})$ are also seen. $\times 30,000$

The cytoplasmic matrix is charactcrized by the presence of microtubules. These are $280 \AA$ in diameter and demonstrated conspicuously by a glutaraldehyde$\mathrm{O}_{\mathrm{s}} \mathrm{O}_{4}$ fixation. Microtubules are observed running in various directions but sparsely distributed in most parts of the cytoplasm. Occasionally, however, they are concentrated in some places to form thick bundles. These bundles are usually attached to the plasma membrane in the free surface with one end and to the basal plasma membrane with the other (Fig. 8); in the attached portions the plasma membranes are always thickened by association with the cytoplasmic materials (Fig. 12, 13). The basal plasma membranes attached to the microtubules are closely apposed to the thickened plasma membranes of the striated muscle fibers, to which thin myofilaments have converged and here make a epithclio-myonal junction (Fig. 13). This attachment does well resemble in appearance the intercalated disc that is regularly found in the cardiac muscle fibers of vertebrates. 


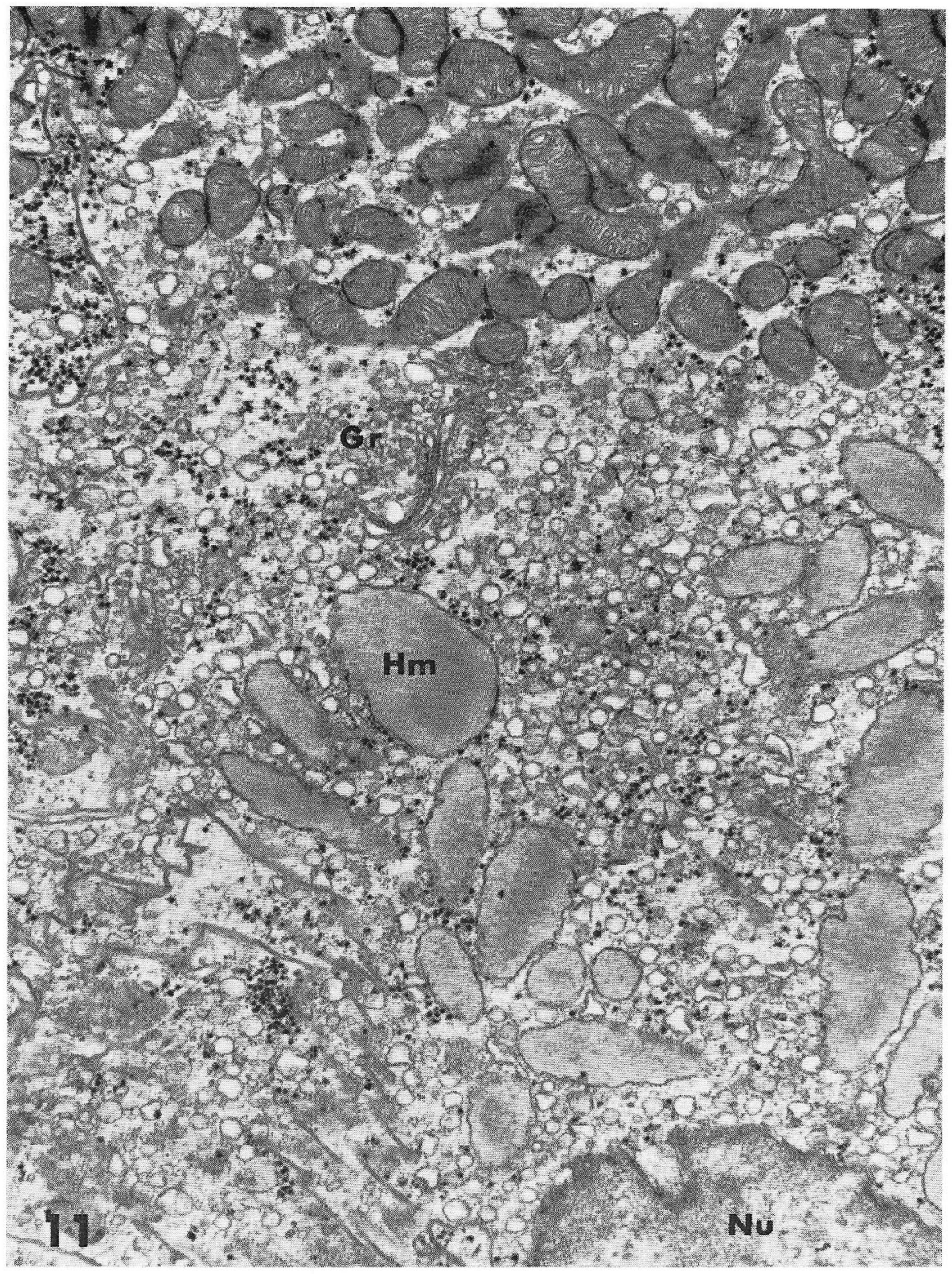

Fig. 11. A supura-nuclear region of the epithelium of the hindgut. Numerous elements of the granular endoplasmic reticulum can be seen mainly in vesicular form ; some are found as dilated cisterns which contain homogencous matcrials $(\mathrm{Hm})$ and are mainly located in a close proximity of the nucleus $(N u)$. Golgi apparatus $(G)$ is also present in this region. Glycogen particles and free ribosomes are scattered in the cytoplasm. $\asymp 18,000$

Fig. 12. The thickened part of the apical plasma membrane which is attached with microtubules $(M t) . \quad \times 18,000 . \quad$ The insertion demonstrates the cross section of microtubules at a high magnification. $\times 36,000$ 
Fine Structure of the Epithelium of Crayfish Gut

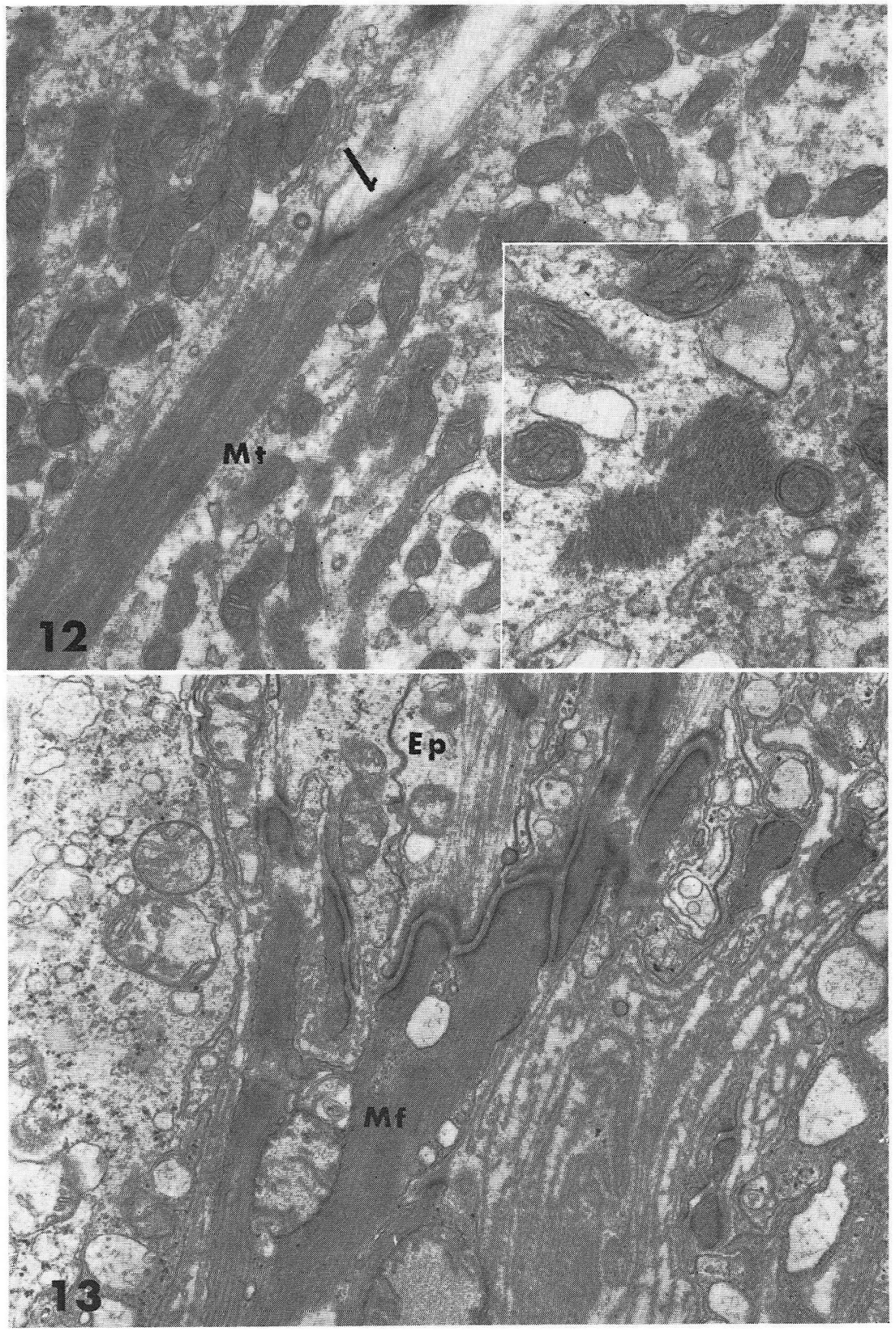

Fig. 13. A high powcr elcctron micrograph of the epithelio-myonal junction in the hindgut. The apposed plasma membranes of epithelial cell $(E p)$ and muscle fiber $(M f)$ are thickened, to which microtubules and thin myofilaments are converged, respectively. «53,000 


\section{Discussion}

\section{Midgut}

As earlier light microscopists pointed out, the midgut of the crayfish may be too short to serve for the absorption of nutrients for the whole body. It is, therefore, reasonable to consider that the midgut might not be a major site for this fuction. However, the present finding indicates that the epithelial cells of the midgut are involved in some specified mechanism of absorption. The apical cytoplasm of the epithelial cells is principally the same in fine structure as that of absorptive epithelial cells in vertebrate intestines. The presence of small vesicles, together with the occurrence of a few intermicrovillous invaginations, may suggest that the epithelial cells function at least in part to absorb some materials. Furthermore multivesicular bodies in the apical cytolasm appear to occur in close relation to the small vesicles above mentioned, probably being formed by a conglomeration of these vesicles.

The supranuclear cytoplasm frequently contains a varitty of vacuoles which are always located close to or near the apical end of the lamellated granular endoplasmic reticulum. Since these vacuoles usually occur singly in individual cells and contain either vesicular, lamellar or homogeneous components or all of them, they are probably not of a secretory but of a lysosomal nature. The vesicular or myelin-figured elements in these vacuoles may be derived from the multivesicular bodies.

The observation that the lamellae of the granular endoplasmic reticulum are particularly well developed in the juxtanuclear cytoplasm, may suggest an active production of protein in these epithelial cells. Furthermore, the well-developed Golgi apparatus is distributed in close relation to these granular endoplasmic reticula. Often the Golgi vesicles contain a dense homogeneous substance, suggesting that some materials are concentrated here. However, no apparent secretory granules are present in the epithelial cells. It is, therefore, presumed that the granular endoplasmic reticulum may be involved in the production of enzymes necessary for the metabolic activity of the cell itself rather than of secretory proteins.

The most interesting feature of the epithelial cells in the midgut is the extensive formation of agranular endoplasmic tubules or lamellae and the abundance of mitochondria in the basal cytoplasm. Since these tubules often open into the intercelluar spaces, they might be derived from the infoldings of the lateral plasma membrane.

Similar structures have been reported in the chloride cells lining the gill filaents of fish (Philpott and Copeland, 1963 ; Yамамото, 1966) and in the special cells of the urinary tubules of the catfish (Yамамото, 1966). These investigators have proposed the hypothesis that the tubular structures might be involved in the concentration and intracellular transport of ions or salts, or in the mechanism of osmoregulation.

From the similarity with respect to tubular structures, we are tempted to consider that the midgut epithelial cells of the crayfish at least in part carry out a function similar to the chloride cell in gill filaments or to the special cells in urinary 
tubules as above mentioned. However, the present study does not furnish any evidence supporting this speculation. Since the cytoplasmic tubules or lamellae are observed confined to the midgut through the whole digestive tract, these structures appear to reflect in any case the proper function of the midgut epithelium.

\section{Hindgut.}

The luminal surface of the epithelium in the hindgut is covered with a thick coat of cuticle. This fact has led to the interpretation that the epithelium of the hindgut does not play a significant role in the absorptive or secretory (JoRDAN, 1904 ; YoNGE, 1963). The cuticular coat in the gut has been thought to protect against abrasion and against proteolytic enzymes (Prosser, 1962). This seems to be the case in the crayfish, and the hindgut does probably function as the main region for feces formation. The cuticular coat is composed of a protein ground substance combined with chitinous fibrils (Prosser, 1962), and shows a lamellated pattern in its constitution. The inner most layer of the cuticle is loose in organization and dose not show a lamellated feature. This layer has been suggested to represent an early stage of cuticule formation (Locke, 1961). Since the cuticular substances have been interpreted to be secreted by the epithelial cells of the hindgut (FrEnZEL, 1885 ; JoRDAN, 1904) this loose layer may represent an accumulation of secretory materials discharged from the epithelium.

In the epithelial cells the granular endoplasmic reticulum is well developed, some parts of which are extremely dilated and contain less dense homogeneous materials, probably proteins. This, coupled with the fact that the cuticle is composed of protein ground substances combined with chitinous fibrils, may support the interpretation that the cuticle is secreted as proteineous substances from the epithelial cells. The well-developed Golgi apparatus may also be involved in this process. However, the apical cytoplasm does not contain such typical secretory granules as are found in the secretory cell of the serous gland. If the materials contained in the dilated granular endoplasmic reticulum are secretory substances, these might be discharged in a manner different from that in other exocrine glands, from the cell surface (probably in vesicular form).

The particular focal concentration of mitochondria in the apical cytoplasm may be assumed to be closely related to the secretory function, if the secretion is actually performed. However, the present study dose not furnish any evidence to cofirm this assumption.

The most noticeable feature in the cytoplasm is the occurence of microtubles. These tubules are observed sparsely distributed throughout the entire cytoplasm, but some of them are grouped to form bundles extending from the apical plasma membrane to the basal. These microtubules are quite similar in appearance to those reported in various animal cells (Slautterback, 1963 ; De The, 1964 ; Behnke, 1964 ; Sandborn, 1964 ; Clark, 1965 ; Silver, 1965 ; Arnold, 1966 ; Lentz, 1967 ; and others) or in plant cells (LedBetter and Porter, 1963 ; Newcomb and Bonnet, 1965 ; Pickett-Heaps and Northcote 1966). Recently the structural details and nature of microtubles have been studied by GALL (1966), BehnKe and Forer, (1967) and SHCLARNSKY and TAYLOR (1967).

Although the shape and size fo microtubules appear uniform in various cells, 
there have been different interpretations on their functional significance; some investigators thought that these tubules may be of contractile or supportive function, whereas others considered that these may be the structure involved in the intracytoplasmic transport or secretory mechanism. The fact that the bundles of microtubules in the present material are attached or anchored to both apical and basal plasma membranes, may support the nature of microtubules as a supporting element.

Of particular interest is the existence of the epithelio-myonal junction in connection with microtubules (VITzou, 1882). The fine structure of the junction, however, has not been elucidated so far. Besides Vitzou, Frenzel (1885) described that the tendon fibers of the muscle extend upward from the base of the epithelium between adjacent epithelial cells and attach themselves to the cuticular coat. Electron micrographs, however, exhibit no collagen fibrils in the intercellular spaces. It is apparent that the tendon fibrils described by Frenzel do apparently correspond to the bundle of microtubules. At the junctional area, the basal plasma membrane attached by the microtubules is closely apposed, with a narrow gap, to the plasma membrane of a striated muscle fiber, to which the myofilaments are converged-an appearance similar to the intercalated disc of cardiac muscle fibers. It might thus be possible to postulate that the force of muscular contraction is conducted to the microtubules of the epithelium through the epithelio-myonal junction and then, finally gives rise to the local traction of rigid cuticular coat.

\section{Summary}

The epithelial cells of the midgut and hindgut in the crayfish were studied by electron microscopy. The epithelial cells of the midgut are characterized by formation of cytoplasmic tubules or lamellae in the basal half of the cells. These structures appear to be specified infoldings of lateral plasma membranes, and are assumed to be similar in terms of structure and function to the cytoplasmic tubular structures in the chloride cell of fish gill filaments. In the hindgut, the epithelial cells are prominently provided with cytoplasmic microtubules. Thick bundles of them are attached to both luminal and basal plasma membranes. When attached with microtubules, the basal plasma membrane of the epithelial cells usually makes an epithelio-myonal junction with that of the processes of striated muscle fibers derived from the muscular coat, in a manner similar to that of the intercalated disc of the cardiac muscles.

\section{ザリガニ腸管上皮の微細構造，ことに細胞内微細小管について（内容自抄）}

\section{アメリカザリガニの腸管上皮を比較解剖学的観点より電子顕微鏡で観察した.}

中腸上皮細胞は，その基本構造において，既知の脊椎動物小腸上皮細胞に似るが，細 胞基底部に見られる管状および板状の膜様構造によって特徴づけられる. この膜様構造 は側面細胞膜の陥入に由来するものと推測される. 形態の類似から, 硬骨魚の鰓のいわ ゆるクロライド細胞，あるいはナマズの尿細管上皮に見られる特殊細胞と同様の機能を 有することが示唆される，後腸上皮細胞では，その遊離面を厚いクチクラによって被わ 
れており，中腸上皮細胞とこの点で大きく異なる，細胞基質内には微細小管がよく発達 しており，しばしば束をなして細胞の長軸方向に走る。その束の一端は遊離面の細胞膜 に付着し，他端は基底細胞膜に付着する. とくに興味あるのほ，細胞内微細小管の付着 する基底部において，上皮細胞は上皮下組織に存在する横絞筋線維との間に接合部を構 成することである。乙れは心筋の介在板に類似した形態を示し，上皮細胞と筋線維の細 胞膜は一定の間隙（約 $200 \AA$ ）をもって相対し，ジグザグの走向をとる。相対する細胞 膜はやや肥厚し，微細小管と微細筋フィラメントが付着している．腸壁の筋線維の収縮 は，上皮筋接合部を介して上皮細胞内微細小管に伝えられ，終局的には硬いクチクラが 率引されて，腸管内腔の大きさが調節されるものと考えられる.

\section{References}

Arnold, J. M. : On the occurrence of microtubles in the developing lens of the squid Loligo pealii. J. Ultrastr. Res. $14: 534-539$ (1966).

Behnke, O.: A preliminary report on "microtubules" in undifferentiated and differentiated vertebrate cells. J. Ultrastr. Res. $11: 139-146$ (1964).

Behnke, O. and A. Forer : Evidence for four classes of microtubules in individual cells. J. Cell Sci. 2: 169-192 (1967).

Clark, A. W. : Microtubles in some unicellular glands of two Leeches. Z. Zellforsch. 68 : 568-588 (1965).

De-The, G : Cytoplasmic microtubules in different animal cells. J. Cell Biol. 23: 265-276 (1964).

Frenzel, J.: Über den Darmkanal der Crustaceen nebst Bemerkungen zur Epithelregeneration. Arch. microsk. Anat. $25: 136-190$ (1885).

Gall, J. G. : Microtuble fine structure. J. Cell Biol. 31: 639-643 (1966).

Grasso, J. A. : Cytoplasmic microtubules in mammalian erythropoietic cells. Anat. Rec. 156: 397-414 (1966).

Huxley, T. H. : Der Krebs. Int. wissensch. Bibliothek 48, Leipzig, Brockhaus, 1881.

Jordan, H.: Die Verdauung und der Verdauungsapprat des Flußkrebses (Astacus fluviatilis). Pflügers. Arch. ges. Physiol. $101:$ 263-310 (1904).

Ledbetter, M. C. and K. R. Porter: A "microtubule" in plant cell fine structure. J. Cell Biol. $19: 239-250$ (1963).

Lentz, T. L.: Rhabdite formation in planaria. The role of microtubles. J. Ultrastr. Res. 17 : 114-126 (1967).

Locke, M. : Pore canals and related structures in insect cuticle. J. biophys. biochem. Cytol. 10: 589-618 (1961).

- The structure of septate desmosomes. J. Cell Biol. 25 : 166-169 (1965).

Loewenstein, W. R. and Y. Kanno : Studies on an epithelial (gland) cell junction. 1. Modifications of surface membrane permeability. J. Cell Biol. 22: 565-586 (1964).

Luft, J. H.: Improvements in epoxy resin embedding methods. J. biophys. biochem. Cytol. 9 : 409-414 (1961).

Millonig, G : A modified procedure for lead staining of thin sections. J. biophys. biochem. Cytol. $11: 736-739$ (1961).

: Advantages of phosphate buffer for $\mathrm{OsO}_{4}$ solution in fixation. J. appl. Physiol. $32: 1638$ (1961).

Newcomb, E. H. and H. T. Bonnett : Cytolasmic microtubule ardd wall microfibril orientation in root hairs of radish. J. Cell Biol. 27 : 575-589 (1965).

Philpott, C. W. and D. E. Copeland: Fine structure of chloride cells from three species of fundulus. J. Cell Biol. 18: 389-404 (1963). 
Pickett-Heaps, J. D. and D. H. Northcote : Organization of microtubules and endplasmic reticulm during mitosis in wheat meristems. J. Cell Sci. 1: 109-120 (1966).

Prosser, C. L. : Feeding and digestion. In : (ed. by) C. L. Prosser and F. A. Brown: Comparative animal phisiology, 2nd ed., Philadelphia, Saunders, 1962. (p. 106).

Sandborn, E., P. F. Koen., J. D. McNabb and G. Moore : Cytoplasmic microtubules in mammalian cells. J. Ultrastr. Res. 11: 123-138 (1964).

Schmidt, E. L.: Observations on the subcuticular layer in the insect integment. J. Morphol. 99: 211-231 (1956).

Sabatini, D. D., K. Bensch, and R. S. Barrnett : Cytochemistory and electron microscopy. The preservation of cellular ultrastracture and enzymatic activity by aldehyde fixation. J. Cell Biol. 17 : 19-58 (1963).

Shelanski, M. L. and E. W. Taylor: Isolation of a protein subunit from microtubules. J. Cell Biol. 34 : 549-554 (1967).

Silver, M. D. : Cytoplasmic microtubules in rabbit platelets. Z. Zellforsch. 68 : 474-480 (1965).

Slautterback, D. B. : Cytoplasmic microtubules. 1. Hydra. J. Cell Biol. 18 : 367-388 (1963).

Vitzou, A. N. : Recherches sur la structure et la formation des téguments chez les crustaces Decapodes. Arch. Zool. expér. 10: 451-576 (1882).

Wiener, J., D. Spiro and W. R. Loewenstein: Studies of an epithelial (gland) cell junction. II. Surface structure. J. Cell Biol. 22 : 587-598 (1964).

Wood, R. L. : Intercellar attachment in the epithelium of Hydra as revealed by electron microscopy. J. biophys. biochem. Cytol. $7:$ 343-352 (1959).

Yamamoto, T. : A method of toluidine blue stain for Epoxy embedded tissues for light microscopy. Acta anat. nippon. 38 : 124-128 (1963).

: Observations on the special cell (type of chloride cell in gill fiament) of the kidney tubules in fresh-water catfish (Parasilus sasitus). 6th Int. Congr. Electron Microscopy, Vol. $2: 675$ (1966).

Yonge, C. M : Evolution and adaptation in the digestive system of the Metazoa. Biol. Rev. 12: 87115 (1937). 